\title{
Politics of the body, fear and ubuntu: Proposing an African women's theology of disability
}

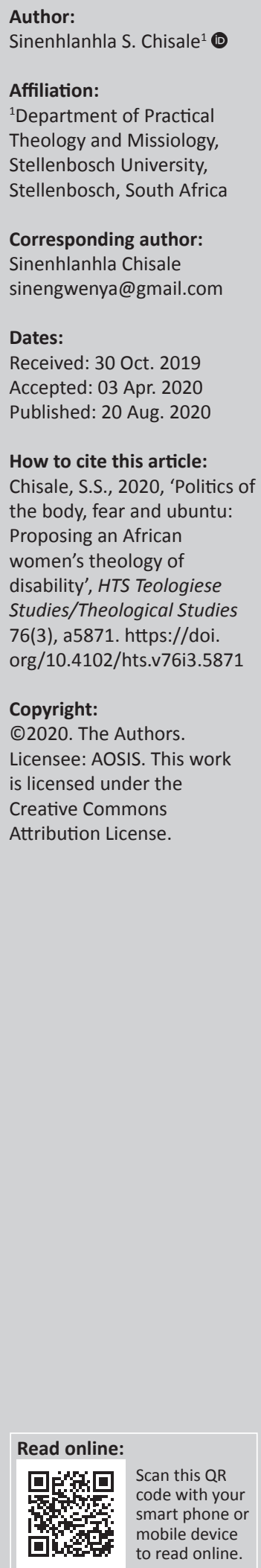

There is increasing research on the inclusion and exclusion of people with disabilities in African spaces, which are perpetuated by religious and cultural fear. Decision to shun or embrace people is defined by the politics of the body and influenced by the religion and culture of fear. In politics of the body, women are discriminated against because their bodies are often controlled and put under surveillance. Women with disabilities experience this discrimination more than their able-bodied counterparts and men with disabilities. Written from the perspective of the ethic of ubuntu, this article examines the fear of disability among the Ndebele of Matetsi in Zimbabwe, as well as how the politics of the body are used by women with disabilities to denounce this fear. These women described how they used (in childhood) and (adulthood) and still use their bodies to call for inclusion in their communities. The article employs findings from the politics of the body emerging from the narratives of women with disabilities to propose an African women's theology of disability.

Contribution: The article problematises fear of disability as a cause of discrimination and exclusion of differently abled people particularly women with. It therefore proposes an African women's theology of disability that is informed by the interdisciplinary approach of Ubuntu promoting the inclusion of all people including women with disabilities into the web of life.

Keywords: ubuntu; inclusion; people with disabilities; African women's theology of disability; politics of the body; religion; culture; women with disabilities; Ndebele; Matetsi; Zimbabwe.

\section{Introduction}

Everyone is born with a disability or is disabled in one way or another. Through society's teachings, individuals develop the ability to use their body parts in the best way that they can for full participation in society. In the same way, as people age, their bodies weaken and they struggle to access freely societal spaces, without assistance. Feminist theologians of disability such as Eiesland (2004) and Kamba (2013) argue that ability is temporary for the human body and that all human bodies have a disability whether apparent or not. The lack of knowledge about a disability has caused African communities such as the Ndebele of Matetsi, to develop a fear of disability. Chisale (2018a:48) refers to this as 'disability phobia'. This phobia develops due to various different perceptions of disability, that are constructed and informed by naive religious and cultural hermeneutics, and negative perceptions of disability.

African women theologians have shown that not only is Christianity informed by the Hebrew Bible and African culture informed by African traditional religions linked and in dialogue with each other (Phiri \& Nadar 2010), they are also informed by social perception. Disability is negatively perceived as a curse and a manifestation of witchcraft in many African communities (Bunning et al. 2017). Similarly, Claassens (2013:56) argues that the 'Hebrew Bible often uses language and imagery related to disability to denote some kind of negative quality.' The kind of language used by the Bible often can create fear and stigma for those with disability. The perceptions of disability by the Ndebele of Matetsi have to do with immorality and impurity. Following Eiesland (1994) who laments that the disabled body is often seen as the opposite of the perfect body, in the context of religious and cultural teachings, on purity laws and menstruation, this interpretation focuses mainly on the feminine body.

The major religions in Matetsi are Christianity, mainly preached in African independent Churches with one mainline church, and African traditional religion, which has a strong focus on purity laws, especially those of purity of the body.

This is parallel to the teachings of the Abrahamic religions (Judaism, Christianity and Islam) on purity laws which focus on women's bodies and impose strong restrictions on menstruating women (Phiri \& Nadar 2010). The purity-impurity and morality-immorality binaries, are used to separate the able-bodied, from the differently abled person, thereby perpetuating inequality in 
society. Following the conservative nature of the African world view, African culture and religion are used to enforce patriarchy which oppresses women (Oduyoye 1995) and enforces ableism.

The same religion and culture are also used to challenge the discrimination against women by reinterpreting misogynistic texts, using a liberative approach (Kanyoro 2002). Phiri and Nadar argue that African women theologians take seriously the simplistic parallels drawn from the Bible and African culture to perpetuate gender inequality in society and church (2010:24).

Thus, religion and culture are barriers to the inclusion of people with disabilities into society among the Ndebele of Matetsi. The impaired body is often perceived as a state of impurity, meaning that it is imperfect, deformed and incomplete.

With respect to the Ndebele people, a deformed or disabled body is referred to as isilima or isigoga. Santos and Santos (2017) explain that the disabled body is therefore seen as both passive and defying socio-cultural notions of normalcy and containment. Susan Wendell a feminist theologian specialising in disability argues that, 'the oppression of disabled people is closely linked to the cultural oppression of the body' (1989:104). In African cultural beliefs, as in the Abrahamic religions, the dominant forms of inequality are linked to the body. Gender inequality makes women, particularly women with disabilities, susceptible to violence, deprivation and poverty. Written from the ethic of ubuntu, this article, on the one hand, discusses how the culture of the fear of disability informed by religio-cultural perceptions and stereotypes, perpetuates discrimination against women with disabilities and, on the other hand, how women with disabilities among the Ndebele of Matetsi contest and resist the discrimination and inequality through the politics of the body.

The article is divided into six sections.

In the first section, I discuss the ethics of ubuntu in the context of the fear of disability. Secondly, I present the methodological considerations by outlining the research process that was followed by the article. The third section highlights how fear informed by religio-cultural perceptions of disability perpetuate the marginalisation, stigmatisation and exclusion of people with disabilities, particularly women with disabilities in Matetsi. In the fourth section, I present the following themes that emerge from the data: fear of disability, imprisoned in a body with a disability, and resisting disability. Furthermore, I critically discuss the emerging themes about the politics of the body as embodied by women with disabilities, in order to denounce the stigma associated with the fear of disability in Matetsi. In the next section, informed by the ethics of the ubuntu philosophy, I present an African women's theology of disability as a theory that promotes inclusion of the differently 'abled' persons and those who do not conform to the normative, for the purpose of equality and human flourishing in African communities such as the Matetsi. Lastly, I offer some concluding remarks about these discussions.

\section{Ubuntu in a context of fear of disability}

Disability is not new or foreign to African communities. In the history of African peoples, people with disabilities existed and their dignity as well as inclusion in society was always promoted through folktales that were told to children.

However, disability has tested the communality of Africans for a long time. Africans defend their communality through the ethic of ubuntu by which everyone and everything is seen to be interconnected, interdependent and integrated.

The concept of ubuntu is at the core of African life. According to Shutte, 'ubuntu embodies an understanding of what it is to be human and what is necessary for human beings to grow and find fulfilment' (2001:2). A person embodies ubuntu (humanness) when he or she is welcoming, respectful of the dignity of others, compassionate, empathetic and caring, and exhibits associated values. The notion of ubuntu is derived from the Nguni dictum, Umuntu ngumuntu ngabantu, that translates as: 'A person is a person through other persons.' In African communities the core value is that no human should exist in isolation or be excluded from the web of life.

Thus, different scholars have conceptualised ubuntu from a communal approach, particularly African women theologians, who argue that, 'the communal principle is the core of African relations' (Kasomo \& Maseno 2011:154-155; Manyonganise 2015). The notion of ubuntu promotes communal relations and interaction between individuals and their respective communities (Dolamo 2013:1). Where we find interdependence, interconnectedness, humanness and communality, there is no fear of a different other. As a result, ubuntu promotes equality, as people are not defined according to their different abilities, race, gender or any dichotomy.

This notion values equality, dignity and existence, whereas dichotomies invoke fear that leads to discrimination, stigmatisation and isolation of those who do not conform to the normative or who are different. On the one hand, fear encourages defensive strategies, such as staying away, avoidance, running away, isolation and exclusion. On the other hand, fear prevents a misfortune. As the Nguni say, Kwabo kagwala akula sililo ['There is no grieving or mourning in the home of a coward']. Thus, fear has positive and negative implications; it is both liberative and oppressive. There is healthy and unhealthy fear. When it comes to disability, unhealthy fear seems to be rife among some ethnic groups including the Ndebele of Matetsi. Fear is connected to the unknown and the supernatural world in traditional African communities, where the fear of sickness, death and witchcraft, permeates every aspect of life. Fear in traditional communities emanates from the suspicion of everything that contradicts the normative. Disability contradicts a normative body and the fear or belief is that it is connected to evil and supernatural ancestral powers. 
I will discuss fear and its implications for African communities later in the article.

\section{Methodological considerations}

This article draws qualitative data from the life history narratives of three female refugees with visual impairments who participated in a project titled, 'Gender-based violence among women and girls with disabilities in relation to sustainable development goals in South Africa', in Johannesburg. Ethical considerations were followed with the guidance of the ethics committee, Department of Health Studies, University of South Africa which subsequently granted the ethics certificate (reference number HSHDC /528/2016) to enable me to commence fieldwork. In line with the mandatory ethics of research, participants were briefed about the research and the process of research. Ethical considerations such as informed consent, identity protection and confidentiality were explained in the participants' language, before the commencement of data collection.

Data was collected through life history narratives and Ndebele, the language of data collection was later transcribed and translated into English. Life history narratives were used because of their flexibility in data collection, which allowed the researcher to collect data from relatively unstructured, informal conversations and stories told by participants in response to the researcher's questions (Sikes, Troyna \& Goodson 1996). The flexibility of this method allowed the researcher to understand and capture people's private perceptions of life (Goodson \& Sikes 2001). The participants came from a particular Ndebele community in Zimbabwe, which means data is limited and not generalised to all Ndebele communities, as the Ndebele culture is diverse.

The Ndebele are found in three provinces of South Africa that include Mpumalanga, Gauteng and Limpopo, and in three provinces of Zimbabwe collectively known as Matabeleland. This article focuses on the Ndebele of Zimbabwe in the Matabeleland provinces, which includes Matabeleland North with a mix of the Ndebele peoples and a few Tonga from Binga. Matabeleland South comprises of the Ndebele, the Tswana, the Sotho and the Venda communities, because it shares its borders with South Africa and Botswana, and with Bulawayo which is the second largest city in Zimbabwe and the capital city of the Ndebele. Various other Zimbabwean tribes converge among the Ndebele. Then, there is the Midlands, which is located in central Zimbabwe between Mashonaland and the Matabeleland provinces and it is home to the Ndebele and Shona peoples of the Midlands. Participants in this study came from the border of Matabeleland South and the Midlands. Two of the participants, Tammy and Lily, come from Matetsi, while Zoey comes from Filabusi, almost 10km from Matetsi. Their Ndebele culture therefore may differ with the Ndebele from other Matabeleland provinces, due to their social location.

The aim of this article is to understand how the culture of the fear of disability that is informed by religio-cultural perceptions and stereotypes perpetuates the discrimination against women with disability. It further explores how women with disabilities among the Ndebele of Matetsi contest and resist this discrimination through politics of the body. Data was analysed through a thematic analysis and themes such as: fear of disability, imprisonment in the disabled body, confronting the fear of disability through the body, emerged.

\section{Fear of disability among the Ndebele}

In their narratives, participants maintained that religion and culture are used to define disability in ways that cause fear of disability in communities. On the theme of fear, participants noted that people in their communities were afraid of a person who looked different from them. Tammy, one of the participants, explained that people fear the disability and not the person. According to Tammy:

'Before the blindness, I was loved and treated equally with other children. Things changed when I became blind because of measles. People isolated me, some ran away from me when I approached them, other children became afraid to share blankets or eat from the same plate with me. It was as if my blindness was contagious.' (In-depth interview 19 February 2017)

Tammy's observation suggests that disability is understood in binary terms, meaning, the person and the disability.

She further said her cousins used to say, 'we are not afraid of you, but we are afraid of your eyes.' Thus, separating disability from the person, promotes fear. Tammy described her experience of blindness when she was in Grade 2 which forced her to drop out of school, because other children were not comfortable around her. She overheard her mother tell her aunt that Tammy would have been better off dead than blind. This resulted in various efforts to heal Tammy. Tammy's mother seems to be in denial about the fact that a person with a disability can live a normal life.

Denial occurs when people refuse to acknowledge a problem. Denial and fear are parallel. People choose to be in denial because they fear something greatly. The interplay of fear and denial became most visible with the diagnosis of HIV and AIDS of persons, as those who discovered that they were infected by HIV resorted to unethical and dehumanising ways of getting rid of the virus for example the virgin cleansing myth, which exposed many young virgin girls to rape in efforts to cure HIV, instead of proven conventional medical treatment to curb the virus and prolong life. The above statements suggest that the family's fear of disability led to denial and different efforts to get rid of the disability. Chisale argues that efforts to heal disability while ignoring the feelings of the disabled child, suggest the presence of 'disability phobia', which then forces people to fight spiritually and physically to get rid of the disability (2018a: 48).

Zoey confirmed Tammy's point that disability is not usually part of a person, as people also described her in binary ways:

'I struggle to connect to my childhood [...]. I do not relate well to my childhood because it is full of sorrow, pain and bad memories 
[...]. I was always referred to as Zoey with a disability (UZoey oyisilima, kumbe oyisiphofu) meaning the deformed or blind Zoey, meaning that there is Zoey and the disability, while other children were referred to with their first names and nothing else. People were afraid of me, when we went for swimming in the river, other children will not come if I am there and those who will come will refuse to swim with me, when I jumped into the water, they came out of water, as if my disability was contagious. It was painful, but I have managed to cope.' (In-depth interview, 12 February 2017)

Zoey further said:

'My aunt gave birth to a daughter without legs and my cousin as isilima (disabled) made things worse for the family [...]. kwasokuthiwa emzini wezilima (meaning home of the disabled) our family was associated with bad omen and a family that is cursed [...]. We were also believed to be witches. No one wanted to associate with izilima (disabled people) because in our family three of us are disabled. It is me who is blind, my cousin uses a wheelchair and my uncle uses crutches [...]. Thus, why we were referred to as home of the disabled, some said home of witches or a home of the disabled.' (In-depth interview, 12 February 2017)

The binary comes through as negative because isilima means 'deformed' and it is regarded as an insult among the Ndebele. When a person calls you an isilima, it means you are not human enough; you cannot think or reason; hence, you are not fit to be called a normal human being. Zoey's pain is justified because referring to her as UZoey oyisilima destroyed her dignity and human worth. Her story also shows that the community associated those with disability with either a bad omen, considered to be cursed or to be witches.

The fear of disability by the Ndebele also emerged from Lily's story, narrated as follows:

'At home, my family used to say, Lawe ubuphofu bakho buyethusa, abantu bayesaba ukungena ekhaya ngendaba zamehlo akho ayesabisayo (meaning, 'your blindness is scaring people who are afraid to enter the yard due to your scary eyes'). Some used to discipline their children using me as a 'rod' to scare their children. They called me 'inunu' [monstrous]. These words are still with me even today; they are still painful.' (In-depth interview, 26 February 2017)

The above narratives indicate that fear of disability is common among the Ndebele, particularly those from Matetsi. According to participants, some people think disability is contagious and some families try all avenues of healing to get rid of it. People seem to be afraid of the actual disability, rather than the person that has the disability. The use of disability to threaten children confirms that the fear of disability is instilled in children, who are taught that a disabled person is monstrous. Surely, such stereotypes instil fear in children who grow up to be indoctrinated into believing that a disabled person is not human, but a monster.

\section{Imprisoned in a body with disability}

Participants also seemed to struggle to connect the self with the disability. Disabilities are treated differently in communities, therefore some participants with disabilities, feel imprisoned in their bodies. Zoey confirmed that the way she was treated, made her hate her body. She said that the way the community treated a person with any disability made that person hate their body. According to Zoey:

'At first, I never really cared about my blindness, but the separation of the disability and Zoey made me hate the body that is carrying Zoey. I love Zoey [the self] not the body. As much as my cousin hates the body that is carrying her, without legs, I hate the body that is carrying me without eyes. The body is the prison forcing people to condemn us, so we spend a lot of time trying to free ourselves from this prison by constructing empowering narratives.' (In-depth interview, 12 February 2017)

The binary distinction between the body and disability is challenged by Zoey who says Zoey (self) is imprisoned in a disabled body. This is informed by how significant others perceive her. The body is always defined and redefined in negative and positive ways by those with whom we interact. The negative harms the self, as confirmed by Zoey who said she hated the body that caused the able-bodied others to define her negatively. Zoey further said, 'God has imprisoned me in this body without eyes.' Apparently, she rejects the narrative of an imprisoned body, as she spends much time trying to free herself from being imprisoned in a body with disability by constructing empowering narratives. Empowering narratives inform the rejection of the culture of the fear of disability.

\section{Resisting the fear of disability through the body}

Participants also explained how they resist the fear of disability or disability phobia through the body. According to Zoey, although some of the community members feared her disability, she tried in every way possible to live a normal life, playing with other kids and going to swim in the river with them and doing all kind of things other kids did, and as an adult, she dated secretly and became pregnant. Zoey said:

'Since people feared my body, I made sure as a child that I allow my body to participate in all things that the so-called 'normal' people do. I used to go and swim in the river. At first, some kids were afraid of me, but they got used to my different body and enjoyed playing with me. I used to play, sing, dance and do everything any other kid will do. Like any other girl, I fell in love and got pregnant.' (In-depth interview, 12 February 2017)

According to Zoey, living a 'normal life' is protesting and contesting the fear of disability. She uses her body to fit into society, play as a child, and love and get pregnant as an adult. When people see a disabled body perform what an ablebodied person can, fear ceases.

Similarly, Tammy said she did not just accept that people treated her differently or were afraid of her. She resisted by acting like a normal person. According to her:

'When other young girls were taken to the river in the morning to be taught about puberty, I cried and screamed that I am also a girl, I also wanted to be taught how to be a young woman. I had already started menstruating and wanted to be taught with other girls as the culture of our community. When they excluded me, my peers would tell me what they were taught. My peers shared 
with me that at the river they were taught labia elongation and how to keep their virginity and what to do when they meet an 'ijaha' (young man), how to behave when an ijaha approaches them. I taught myself all these things through the help of peers. My aunts and mother were surprised that I knew those things. They only discovered that I was sexually active and had a boyfriend when I became pregnant.' (In-depth interview, 19 February 2017)

\section{Lily said:}

'I fell [sic] pregnant because I am a normal woman. I have sexual feelings like any other woman. I can carry a baby in my womb, and I am able to go into labour and deliver a normal and healthy child. My sexuality does not have a problem; it is only my eyes that are blind. The rest of my body is abled [sic], I have a womb, I have genitals, so denying us to love and be loved, to have our own biological children is not right [...]. Did you know that some people believe that people with disabilities give birth to disabled children? That is why some communities kill children with disabilities to get rid of a disability in the family.' (In-depth interview, 26 February 2017)

It emerges from the three responses, that the body is used to confront the fear of disability. Participants confirmed that they use their bodies to perform what is expected of a 'normal' body. As children, they used their bodies to challenge fear by playing, singing, dancing and swimming, just like any other child.

Adolescents challenge the fear of disability by participating in rites of passage with the help of peers, and young women become pregnant, give birth and nurse their babies. Participants noted that they used their bodies to resist the stereotypes that perpetuate the fear of disability. Fear promotes discrimination, denial, shame and stigma associated with disability. Fear leads to sin because those who are afraid, in particular of disability, undermine the dignity of those living with disability in an effort to protect themselves.

\section{Why is there fear of disability?}

Since religion literally perceives disability as a curse from God, or the ancestors, people with disabilities and their families are often discriminated against. It is documented in literature that, in the past, most African families used to hide children with disabilities at home because of the fear of stigma (Ngubane-Mokiwa 2018:4). The families of disabled children feared the community's attitude towards them as well as the wrath of ancestors. Furthermore, disability among the Ndebele of Matetsi is associated with bad luck and witchcraft and is seen as a form of communication by the ancestors. These perceptions force families to hide children or family members with a disability, by locking them in the house and out of sight of the community (Ngubane-Mokiwa 2018:4). Hiding people with disabilities means that other members of the community rarely see them. Since seeing a person with a disability was associated with a bad omen, this resulted in fear which then forced communities to construct their own laws to protect the community from these bad omens.
In a Contextual Bible Study ${ }^{1}$ with the Prayer Women's League (PWL) from my church, which was meant to commemorate the International Day of Persons with Disabilities, we read in John 5:1-15 where Jesus healed a disabled man at the Pool of Betheseda. In discussions about disability, women insinuated that in ancient African communities, meeting a disabled person on the road or in a public place was umnyama [bad omen or bad luck] and that meeting a person with a disability was linked to witchcraft. The fear of a bad omen or bad luck on its own, strongly invoked the fear of meeting a person with a disability, or the fear of giving birth to a child with disability.

\section{Problematising the fear of disability in an African context}

The notion of fear has been problematised because it alienates people from one another and breeds suspicion (Furedi 2002). Frank Furedi in his book titled, Culture of fear: Risk-taking and the morality of low expectation, explains how a culture of fear can destroy and disrupt the social relations and fabric through suspicion. He further notes that the September 11 attacks in the United States of America in 2001, encouraged some Americans to fear the wrong things (2002:xvii), for example some people from Muslim countries are associated with terrorism, shaking hands is associated with contracting infection (Furedi 2002:xiv). Fear causes people to say or do despicable things. Some become violent, beat or kill the person or thing about which they have a phobia. For example, black South Africans are accused of being xenophobic by resorting to violence in order to get rid of foreigners. However, there are questions about the nature of the attacks on foreign nationals in South Africa whether they are incited by xenophobia, Afrophobia, self-hatred or self-fear. It is not clear if these attacks are due to the fear of foreigners or the fear of competing with foreigners. Either way, the idea of xenophobia in South Africa is ambiguous.

Whereas Americans and Western countries see fear in the light of the known and historical events that have taken place (Furedi 2002:vii), for many Africans, fear is ambiguous, and it is the fear of the unknown. Africans are dominated by the fear of the supernatural world, which includes both the ancestors and God. It is believed that ancestral and supernatural powers control the lives of the living; they can therefore both curse and bless the living. As a result, misfortune is viewed with suspicion. Many Africans believe that witches or ancestors have a hand in everything that happens in their lives (Mbiti 1969:68). A misfortune or anything that disturbs human flourishing and the balance of the 'web of life', particularly, sickness, accident, death, divorce, infertility, disability and bad luck is suspected to be due to witchcraft or the anger of ancestors (Manala 2004; Mbiti 1969). Personal misfortunes and occurrences that contradict the normative, are always suspiciously linked to supernatural causation. The culture of suspicion has reinforced dangerous and dehumanising stereotypes because

1.This article does not present the CBS findings, but it does employ some statements from the CBS to substantiate the argument. 
suspicion invokes fear. Disability in the eyes of the Ndebele of Matetsi is not explained from a social or medical perspective, but from a spiritual perspective that relates to God and the ancestors. Thus, John Mbiti's argument that Africans are notoriously religious (1969:1) sheds light on the genesis of their world views. Fear is used to control the society and religion, and with its supernatural mysteries, makes this worse.

Among the Ndebele of Matetsi, disability is feared and considered a project of the ancestors (Chisale 2018b:1).

A person living with disability is known as isilima [a deformed/incomplete body or an impairment]. A child born with a disability is treated as a special case and is discriminated against and isolated. Religiously and spiritually, the Ndebele believe that either the ancestors are communicating through the person with the disability that is a curse, or the person is a special being sent to the family. Thus, the birth of a child with a disability causes stress and trauma in the family (Mathebane 2015:167). The social approach emerges from the narrative that describes resistance of disability phobia. Participants confirmed that they use their bodies to fit socially into the community by performing the normative or what is expected of an able-bodied person. I therefore use the politics of the body to propose an African women's theology of disability, that promotes the inclusion of different others and those who do not conform to the normative.

\section{Disrupting fear of disability: Towards an African women's theology of disability}

I propose an African women's theology of disability because it has liberative elements informed by ubuntu that is promoted by the African culture of communality. This theory defends the positive elements of culture that promote inclusion and equality. According to Claassens, we are encouraged to 'find a different kind of [theological] speech regarding disability rooted in values such as human dignity, inclusion and hospitality' (2013:57). African women's theology of disability reimagines humanity from God's image, from which all are made. Participants confirm this in their efforts to resist fear, as they use their body to fight for inclusion and develop a liberative narrative of disability. The key themes that emerge and inform the resistance of the fear of disability are: inclusion and African communality or ubuntu.

\section{African women's theology of disability is inclusive}

The proposed African women's theology of disability rejects the exclusion of 'the other' in African communities, in this case women with disabilities. It emerges that fear of disability is a human invention; communities are taught through naive hermeneutics of culture and religion to fear disability. Since the fear of disability is a human invention, women with disabilities use their bodies to resist this fear by reinventing liberative images of disability that defy the normative body.
An African women's theology of disability therefore calls for the inclusion of all women in the fight against the oppression of the female body. This is because the normative is a myth that perpetuates exclusion through dichotomies of ableddisabled, male-female, white-black, heterosexual-homosexual, and so forth. The normative has contributed to the nurturing of ableism, patriarchy, racism and heterosexuality. Thus, in African women's theology of disability, 'there is neither Jew nor Gentile, neither slave nor free, nor is there male and female, [nor abled and disabled] for you are all one in Christ Jesus' (G1 3:28, author's own). Oneness means likeness and equality, which promotes the inclusion of all people according to the value of human dignity.

It emerges from the participants in this study, that fear of disability is perpetuated by naive hermeneutics, particularly of the Hebrew Bible on disability, and the ambiguity of African spirituality on the connection of ancestors with disability. In such hermeneutics God and ancestors are feared yet acknowledged as a source of life. How can a source of life be feared when it brings life and removes all the barriers that hinder inclusion? In the African contexts, God and the ancestors join the community together and protect it from anything that threatens this unity.

The African women's theology of disability reimagines God and the ancestors as a source of life and inclusion, rather than a source of curse or misfortune. A child born alive into a family is a blessing regardless of ability or disability.

This emerges from Zoey who explains the binary that emerges from the community and the self about her disability. According to Zoey, there is a person on one hand and a disability on the other. This challenges the communities to respect the person because she or he is a person, so it is the personhood that should be respected and difference, in this case such as a disability, should be embraced as diversity. The most significant aspect of the African women's theology of disability, is respect and inclusion of diversity which values human dignity, while at the same time, acknowledging different capabilities. Ackermann (1991:94) rightly argues that human dignity is the starting point for all theology including the African women's theology of disability. The respect for a participants' personhood led to the embracing of their disability. Participants of this article confirmed that they protested against the fear of disability, because it was threatening their dignity and self-worth. The personhood inside the body was prioritised in order to negotiate the inclusion of the body living with a disability. Inclusion into society of people with disabilities is promoted by Black (1996) who argues that God is an inclusive God. Therefore, inclusion should be at the core of church praxis because Christianity is founded on the inclusive Christ. In agreement, African women's theology calls for the inclusion of lay and ordained African women in the theological curriculum (Phiri 2009). African women argue that Africans are interconnected and interdependent based on their principle of communality (Kasomo \& Maseno 2011). The communality principle does not exclude anyone or anything, and it informs the view of 
African women's theology of disability which is that all Creation is interdependent. A woman with a disability is as much a woman as all other women, a person as all other persons and made in the image of God as all other humans. This understanding of human beings promotes communality which is a principle of ubuntu and inclusion. The idea of communality is discussed under ubuntu in the next paragraph.

\section{African women's theology of disability and ubuntu}

Inclusion and ubuntu are interrelated, as inclusion is a principle of ubuntu. The binaries that exist in communities create fear, stigma and discrimination which affect those who do not conform to the normative. The notion of ubuntu rejects binaries or dichotomies because it promotes interdependence, interconnectedness and interpersonal networks of life (Shutte 2001:12). In the same vein, African women's theology of disability is informed by ubuntu because it embraces the values of the African world view of solidarity, humanness, caring, sharing, respect, compassion and other associated values. The notion of ubuntu captures the inclusive metaphors of God, thereby, promoting the interrelationship between Creation and God. The narratives of the experiences of the participants in their Ndebele communities, suggest that the Ndebele do not promote inclusion of people with disabilities, but people with disabilities among the Ndebele negotiate their own inclusion through the use of their bodies. Although the participants perceived their body as a prison, they highlighted that they were able to create liberative narratives of disability that free them from feeling captured and imprisoned in a body with a disability. They do this by defying the normative and by making the community conscious of the ablility of the disabled body.

Their response to fear has undertones of ubuntu where the victim does not respond to oppression violently, aggressively, silently or compliant, but through negotiation of her own hospitality and inclusion. Participants negotiated their inclusion through challenging ableist constructions; that is, it is only an able body that can swim, dance, be sexually attractive, falls in love, has sex and give birth. They defied the normative of sex and motherhood by speaking directly to the concerns of the African women's theology of disability. African women's theology of disability rejects the normative because of its exclusion biases. By defying the normative, participants' resistance and contestations yielded positive results because in the end communities accepted and embraced them. This suggests that for liberation and inclusion to take place, victims of exclusion should negotiate their own inclusion through resistance. African women's theology of disability gives the victim a voice to protest and negotiate for inclusion.

The interdependence on peers to learn about puberty rites, is centred on ubuntu. Participants confirmed that when they were excluded from puberty and sexual rites due to their disability, peers came back and shared with them what they were taught and how. Reynolds confirms this as he argues that 'vulnerability and dependence is normal' (2008:129). With ubuntu the value of other people is important, as Banda and Mudzanire (2019:4) state that 'ubuntu upholds the human dignity and value of other people.' This means that human beings are obliged to protect the dignity of one another. When one person's dignity is devalued and stripped, every member of the community loses dignity. In such contexts, ubuntu decries discrimination and stigma but promotes love, compassion, solidarity, inclusion, instead.

The African women's theology of disability rejects discrimination and stigmatisation of the different other, by acknowledging the interdependence of humanity with each other. This confirms that interdependence is not a give and take principle, but it sometimes involves giving and giving, and not give and taking, because ubuntu promotes caring and compassion (Broodryk 2008). This caring and compassion negotiates and escorts the process of inclusion, where the different other and those without, are part of the community. In such relationships, dichotomies do not exist, but there is mutual love and appreciation.

The African women's theology of disability can be seen to reject individualism and segregation of people, based on dichotomies.

Everyone and everything exist in a 'web of life', where there is no space for stigma or discrimination. Chisale (2018c:4) claims that living in a web of life was the purpose of God's Creation, as a result of which, existing in a community and having right relationships with each other is a principle of morality. If a child with a disability is born into a community, his or her resistance to the fear of disability and experiencing inclusion, are shaped by her or him as she or he influences the relationships she or he has with a community. Inclusion is the core of the African women's theologising of their lived experiences, because they defend the image of God in them. They regard ubuntu as a major theme in their theologising, because it acknowledges the interdependence and interconnectedness of Creation through right relationships (Oduyoye 1990). It can be seen that ubuntu has religious features because interdependence and interconnectedness promoted by ubuntu include the right relationships with God, the living dead (ancestors), and all Creation. This renders discrimination, stigmatisation and exclusion as sinful and ungodly.

As such, African women's theology of disability embraces and adopts ubuntu because its religious character acknowledges that God's plan includes interdependence of all Creation. In this sense, African women theology of disability touches the heart of African communities.

\section{African women's theology of disability as an embodiment of inclusion}

The African women's theology of disability emerges from the feminist theology of disability but builds heavily on the foundation laid by the Circle of Concerned African Women 
Theologians (hereafter the Circle) which relates to the lived experiences of African women. The African women's theology of disability develops from the politics of the body and the dis(ability) politics that are informed by culture and religion. Although women with disabilities experience gender injustice more than able-bodied women and their male counterparts (Chindimba 2011), they reimagine their bodies and impairments in relation to God. For example, Nancy Eiesland argues that the risen Christ in Luke 24:36-39 embodies a 'disabled God' (1994:70). Jennie Weiss Block, writing also from a disability perspective, argues that God is accessible to everyone and every creation; thus 'people with disabilities should take their rightful place within the Christian community' and claim Christ as their saviour (2002:11).

Kathy Black argues that God is an inclusive God for 'we are all interconnected and interdependent upon one another so that we do affect the lives of others and the earth itself' (1996:34). This is parallel to the view of African women's theology that promotes the African communality principle, based on the African philosophy that says 'I am because we are and since we are therefore, I am' (Mbiti 1969:108-109). For African women theologians, community is the principal theme that challenges patriarchy by reminding societies that African communities are built on interdependence and interconnectedness (Kanyoro 1996; Oduyoye 1990). Eiesland interprets this interdependence and interconnectedness as a challenge to all women, with and without disabilities, who need to be aware that collectively we are 'a body in trouble' (1994:116). Thus, the African women's theology of disability's focus on the inclusion of the body, includes all marginalised bodies and contributes to a holistic and sensitive pastoral approach.

The oppression of the body of a woman living with impairment is the oppression of all women's bodies. The African women's theology of disability therefore acknowledges that women's struggles are interconnected, regardless of the abilitydisability dichotomy. This is because patriarchy constructs and justifies the control of the feminine body. Philosophers like Aristotle perceived women as a deformed male because their genitals are internal compared to those of men which are external. Aristotle argues that:

'[J]ust as it sometimes happens that the deformed offspring are produced by deformed parents, and sometimes not, so the offspring produced by a female are sometimes female, sometimes not, but male. The reason is that the female is as it were a deformed male.' (in Fantham et al. 1994:191)

The perception of defining a woman as a 'deformed man' affects all women and men across society, calling all women and men to unite in fighting stereotypes that restrict and exclude people because of their body impairment.

Eiesland (1994) rightly argues that the ability of the body is temporary. As the body goes through developmental stages, it loses its strength and becomes disabled; or from a radical viewpoint, some people's impairments result from accident and sickness. The restriction of a deformed body from holy spaces is recorded in Abrahamic religions. For example, the Levitical code commands that:

'[N]one of your descendants who has a defect may come near to offer the food of his God ... no man who is blind or lame, disfigured or deformed; no man with a crippled foot or hand, or who is a hunchback or dwarfed, or who has any eye defect, or who has festering or running sores or damaged testicles ...' (Lv 21:16-21)

This challenges men to be in solidarity with women because their masculine body or ability can be castrated by naive religious and cultural hermeneutics.

The African women's theology of disability emphasises solidarity, as women with their diverse bodies work together to fight against oppression and patriarchy. Ackermann (2008:272) says any form of oppression of the marginalised, calls all those who are affected to unite in resistance and those who are concerned to be in solidarity. Men who seem to be favoured by the literary translations of religious teachings are challenged to be in solidarity, not only as friends but also as 'future victims'. Thus, the African communality principle challenges communities to have mutual relationships whereby the pain of one member is the pain of the whole community.

For this reason, solidarity promotes cohesion and harmony of all members regardless of whether they are disabled or able-bodied, women and men. African women's theology of disability therefore is a strand of African women's theology that pastorally sensitises communities to their fragility.

The fragility of the human body is evident in the Crucifixion of the body of Christ, who on the Cross becomes fragile, weak and vulnerable (astheneia). Reynolds explains that human beings experience the glory of God in this frailty and weakness, because 'God not only acts in solidarity with weakness, God acts through weakness' (2008:231). In agreement Louw (2014:7 of 10) describes the weakness of Christ on the Cross as God revealing his weakness and vulnerability to the world. For Louw (2014) God is connected to human vulnerability and suffering through the Crucifixion and death, Resurrection transforms the pain of human suffering into renewed divine hope. The frailty and vulnerability of Christ on the Cross is theological inclusive; this is evident when Christ assured a penitent criminal who was crucified with him of a place in paradise (Mt 27:38, Lk 23:32-43 and Mk 15:27).

The African women's theology of disability embraces this inclusive love of Christ on the Cross, as a prospect of breaking barriers of exclusion due to different body shapes or forms.

\section{Conclusion}

This article demonstrates that African women's theology of disability is relevant not only to the disabled community, but also to all Creation, human and non-human. The theory 
is significant mainly in pastoral ministry as it calls for the rights and dignity of the vulnerable communities, particularly the most at risk populations (MARPs). The MARPs are discriminated against and stigmatised due to their different bodies and, at times, due to illnesses that have attacked their bodies. The article highlights that the crux of African women theology of disability, is inclusion. For inclusion to take place, the normative should be deconstructed and reconstructed in an inclusive way, where disability is normal (Reynolds 2008). The African women's theology of disability recognises the politics of the body as resistance to the normative, while promoting the African communality principle that is centred on the notion of ubuntu. In the struggle for inclusion, African women's theology of disability acknowledges that the dependence of those with disabilities is linked to ubuntu's call of solidarity, compassion and care. The body is therefore reimagined from the image of God and the Crucifixion of Christ, where all can enjoy his inclusive love.

\section{Acknowledgements}

This article is part of the postdoctoral project titled: Politics of the Body and Resistance: Pastoral Care in a context of disability, sexuality, migration that is part of the broader research project titled: 'Transgression and Transformation: Fostering a hermeneutically ethical world' by Professor Juliana Claassens in the Gender Unit, Faculty of Theology, University of Stellenbosch.

\section{Competing interests}

The author declares that she has no financial or personal relationships which may have inappropriately influenced her in writing this article.

\section{Author's contributions}

I declare that I am the sole author of this research article.

\section{Ethical consideration}

University of South Africa, Research Ethics Committee: Department of Health Studies, RE-012714-039 (NHERC)

\section{Funding information}

This research received no specific grant from any funding agency in the public, commercial or not-for-profit sectors.

\section{Data availability statement}

Discussions in this article draw on existing data from the author's own work, which is duly acknowledged.

\section{Disclaimer}

The views and opinions expressed in this article are those of the author and do not necessarily reflect the official policy or position of any affiliated agency of the author.

\section{References}

Ackermann, D.M., 1991, 'Being woman, being human', in D. Ackermann, J. Draper \& E. Mashinini (eds.), Women hold up half the sky: Women in the church in Southern Africa, pp. 93-105, Cluster Publications, Pietermaritzburg.

Ackermann, D.M., 2008, 'Found wanting and left untried? Confessions of a ragbag theologian', in M. Pillay, S. Nadar \& C. Le Bruyns (eds.), Ragbag theologies: Essays in honour of Denise M Ackermann a feminist theologian of praxis, pp. 265-282, SUN Press, Stellenbosch.

Banda, C. \& Mudzanire, S., 2019, 'Supplementing the lack of ubuntu? The ministry of Zimbabwe's Mashoko Christian Hospital to people living with HIV and AIDS in challenging their stigmatisation in the church', HTS Teologiese Studies/Theological challenging their stigmatisation in the church', HTS Teologiese Stud
Studies 75(4), a5468. https://doi.org/ 10.4102/hts.v75i4.5468

Black, K., 1996, A healing homiletic: Preaching and disability, Abingdon Press, Nashville, TN.

Block, J.W., 2002, Copious hosting: A theology of access for people with disabilities, Continuum, New York, NY.

Broodryk, J., 2008, Understanding South Africa: The ubuntu way of living, Ubuntu School of Philosophy, Pretoria.

Bunning, K., Gona, J.K., Newton, C.R \& Hartley S., 2017, 'The perception of disability by community groups: Stories of local understanding, beliefs and challenges in a rural part of Kenya', PLoS One 12(8), e0182214. https://doi.org/10.1371/journal. pone.0182214

Chindimba, A.T., 2011, 'The place of women with disabilities in feminist movements', Journal on African women's experiences 1(2), 98-100.

Chisale, S.S., 2018a, 'Experiences of violence and self-perceptions of visually impaired refugee women in South Africa and implications for pastoral care', Journal of Theology for Southern Africa 160, 40-57.

Chisale, S.S., 2018b, 'Disabled motherhood in an African community': Towards an African women theology of disability', In die Skriflig 52(1), a2375. https://doi. org/10.4102/ids.v52i1.2375

Chisale, S.S., 2018c, 'Ubuntu as care: Deconstructing the gendered ubuntu', Verbum et Ecclesia 39(1), a1790, https://doi.org/10.4102/ve.v39i1.1790

Claassens, J.L., 2013, 'Job, theology and disability: Moving towards a new kind of speech', in J.L. Claassens, L. Swartz \& L. Hansen (eds.), Searching for dignity
conversations on human dignity, theology and disability, pp. 55-66, SUN MeDIA, conversations

Dolamo, R., 2013, 'Botho/Ubuntu: The heart of African ethics', Scriptura 112(1), 1-10. https://doi.org/10.7833/112-0-78

Eiesland, N.L., 1994, The disabled God: Toward a liberatory theology of disability, Abingdon Press, Nashville, TN.

Eiesland, N.L., 2004, Encountering the disabled God, viewed 12 February 2016, from https://www.biblesociety.org.uk/uploads/content/bible_in_transmission/ files/2004_spring/BiT_Spring_2004_Eiesland.pdf.

Fantham, E., Shapiro, H.A., Foley, H.P. \& Kampen, N.B., 1994, Women in the classical world: Image and text, Oxford University Press, New York, NY.

Furedi, F., 2002, Culture of fear: Risk-taking and the morality of low expectation, revised edn., Continuum, London.

Goodson, I.F. \& Sikes, P., 2001, Life history research in educational settings, Open University Press, Buckingham.

Kamba, M.K., 2013, Developing a holistic educational programme through contextua Bible study with people with disabilities in Kinshasa, Democratic Republic of Congo: IMAN'ENDA as case study, PhD thesis, University of Kwa-Zulu Natal, Pietermaritzburg.

Kanyoro, M.R.A., 1996, 'God's calls to ministry: An inclusive hospitality', in M.R.A. Kanyoro \& N.J. Nyambura (eds.), Groaning in faith: African women in the household of God, pp. 149-160, Acton Publishers, Nairobi.

Kanyoro, M.R.A., 2002, Introducing feminist cultural hermeneutics: An African perspective, The Pilgrim Press, Cleveland, $\mathrm{OH}$.

Kasomo, D. \& Maseno, L.M., 2011, 'A critical appraisal of African feminist theology', International Journal of Current Research 2(1), 154-162.

Louw, D.J., 2014, 'Virtuous suffering and the predicament of being handicapped. Towards a theology of the "disabled God puffing in a wheelchair", In die Skriflig/ In Luce Verbi 48(1), Art. \#1692, 10 pages. https://doi.org/10.4102/ ids.v48i1.1692

Manala, M.J., 2004, 'Witchcraft and its impact on black African Christians: A lacuna in the ministry of the Hervormde Kerk in Suidelike Afrika', HTS 60(4), 1491-1511. https://doi.org/10.4102/hts.v60i4.635

Manyonganise, M., 2015, 'Oppressive and liberative: A Zimbabwean woman's reflections on Ubuntu', Verbum et Ecclesia 36(2), Art. \#1438, 7 pages. https://doi. org/10.4102/ve.v36i2.1438

Mathebane, M. 2015, 'The lived experiences of black African mothers following the birth of a child with down syndrome: Implications for indigenisation of social work', Social Work/Maatskaplike Werk 52(2), 166-187. https://doi. org/10.15270/52-2-499

Mbiti, J.S., 1969, African religions and philosophy, Doubleday, New York, NY.

Ngubane-Mokiwa, S.A., 2018, 'Ubuntu considered in light of exclusion of people with disabilities', African Journal of Disability 7, a460. https://doi.org/10.4102/ajod. v7i0.460

Oduyoye, M.A., 1990, Who will roll the stone away? The ecumenical decade of the churches in solidarity with women, WCC, Geneva.

Oduyoye, M.A., 1995, Daughters of Anowa: African women and patriarchy, Orbis Books, Maryknoll, New York, NY. 
Phiri, I.A., 2009, 'Major challenges for African women theologians in theological education (1989-2008)', International Review of Mission 98(388), 105-119. https://doi.org/10.1111/j.1758-6631.2009.00009.x

Phiri, I.A. \& Nadar, S., 2010, 'Talking back to religion and HIV \& AIDS using an African feminist missiological framework: Sketching the contours of the conversation' Journal of Constructive Theology 16(2), 8-24.

Reynolds, T.E., 2008, Vulnerable communion: A theology of disability and hospitality, Brazos Press, Grand Rapids, MI.
Santos, A.C. \& Santos, A.L., 2017, “'Yes, we fuck!” Challenging the misfit sexual body through disabled women's narratives', Sexualities 21(3), 303-318. https://doi. org/10.1177/1363460716688680

Shutte, A., 2001, Ubuntu, Cluster Publications, Pietermaritzburg.

Sikes, P., Troyna, B. \& Goodson, I.F., 1996, 'Talking lives: A conversation about life history Taboo', The Journal of Culture and Education 1, 33-54.

Wendell, S. 1989, 'Toward a feminist theory of disability', Hypatia 4(2), 104-124. https://doi.org/10.1111/j.1527-2001.1989.tb00576.x 